\title{
Pyrolysis characteristics and kinetics of Indian low rank coal using thermogravimetric analysis
}

\author{
Krishna Kant Dwivedi ${ }^{1}$ (D) P. K. Chatterjee ${ }^{2}$ M. K. Karmakar ${ }^{2}$ A. K. Pramanick ${ }^{1}$
}

Received: 30 September 2018/Revised: 7 December 2018/Accepted: 12 January 2019/Published online: 23 January 2019

(C) The Author(s) 2019

\begin{abstract}
The present research work deals with the thermogravimetric analysis (TGA) and kinetic analysis of three typical Indian low rank coals selected from Indian coal mines at various temperature ranges. Experiments were performed at four different heating rate $(50,100,150,200 \mathrm{~K} / \mathrm{min})$ for three typical Indian low rank coal samples in a nitrogen atmosphere from temperature range $30-950{ }^{\circ} \mathrm{C}$. The peak of temperature and mass loss for Indian low rank coal were evaluated. Current study also deals for the utilization and the behaviour of Indian low rank coal during the pyrolysis by using TGA. The activation energy for Indian low rank coal were calculated based on TGA data by using Friedman Method. Corresponding calculated mean value of activation energy for Indian low rank coal is found $49.132 \mathrm{~kJ} / \mathrm{mol}$. These experimental results help to explain and predict the behaviour of Indian low rank coal in practical applications.
\end{abstract}

Keywords Kinetics $\cdot$ Nitrogen environment $\cdot$ Pyrolysis $\cdot$ TGA $\cdot$ Waste coal

\section{Introduction}

Pyrolysis is a thermochemical treatment of any organic (carbon based) product at particular temperatures range in the absence of oxygen. The study of pyrolysis includes the changes in chemical composition and characteristics of physical phase (Buratti et al. 2015). This process includes the decomposition of coal's organic structure and the releases of volatile matter up to $70 \%$ weight loss. The ignition point, rate of combustion and particle emission can be figured out with the help of pyrolysis of coal (Bach and Chen 2017; Chandrasekaran et al. 2017; Cor et al. 2000). This is a method for producing char to improve its calorific value. Thermal decomposition of coal plays key role in

Krishna Kant Dwivedi

kkdwivedi44@gmail.com

1 Department of Mechanical Engineering, National Institute of Technology, Durgapur, West-Bengal 713209, India

2 Energy Research and Technology, CSIR-Central Mechanical Engineering Research Institute, Durgapur, West-Bengal 713209, India gasification and co-combustion of coal (Kelebopile et al. 2011; Kajitani et al. 2006). During the pyrolysis of coal two processes take place first is depolymerisation in which water vapour, gas and tar are formed and secondly repolymerization process when char forming takes place (Zhang et al. 2015; Naveen and Premalatha 2014; Li et al. 2014, 2017). Mass loss of coal with respect to time and temperature can be measured by using pyrolysis (Duan et al. 2016, 2017). Pyrolysis characteristics and its kinetics are important factor to estimate the utilization of low rank coal. The kinetics model and pyrolysis characteristics of coal helps in developing pyrolysis technology and pyrolysis reactor (Feng et al. 2016; Ferrara et al. 2014). Gasification and pyrolysis are the common way for utilization of low rank coal (Cai et al. 2008; Idris et al. 2010, 2012). In India large amount of low rank coal are reserved in different coal mines. Low rank coal cannot be conveniently used because it has low calorific value and high ash contents (Jayaraman et al. 2017a, b, c). Basically low rank coal is mainly used for power generation by fire power plant around the colliery creating large scale pollution. This category of coal is abundant in several coal mines, coal 
washeries in India (Jayaraman et al. 2017a, b, c). So it is necessary to mitigate the above problem in order to use waste coal as efficient as possible. TGA is a simple and accurate method to calculate the reaction rate and change of mass with function of temperature. Property and behaviour of coal sample also can be measured by using TGA including composition, purity, decomposition reaction and absorbed moisture contents (Jain et al. 2016). Basically this method has been used by many researchers to determine the reactivity of coal (Cheng et al. 2015). Thermogravimetric analysis is helpful to calculate the important parameter like starting and ending temperature for combustion process fuel reactivity etc. that are required for proper design of boiler and to estimate the design factors such as excess air, residence time, combustion efficiency (Geng et al. 2015; Gao et al. 2015).

Previously many notable works has been reported on TGA but there has never been an attempt to determine the pyrolysis kinetics of Indian low rank coal. Therefore, this article encompasses the experimental study on the thermal decomposition and kinetics of Indian low rank coal by using a thermogravimetric analysis (TGA) technique. Pyrolysis characteristics and kinetics parameter are important tools to improve pyrolysis technologies and design of pyrolysis reactors. Kinetic parameters obtained through TGA mostly required for efficient CFB boiler design and maintenance by computational fluid dynamics (CFD) simulation. So Thermogravimetric analysis (TGA) of Indian low rank provides the easiest technique to determine the kinetic characteristics. Many previous work conducted to study about TGA method for different countries low rank coal such as low rank Malaysian coal (Idris et al. 2010), Chinese Shenhua Raw Coal (Wang et al. 2016) and Waste coal (Ningxia Province of China) (Song et al. 2016).

In this present work, the pyrolysis characteristics and kinetics of Indian low rank coal were investigated by TGA in nitrogen atmosphere with different heating rates $(50$, $100,150,200 \mathrm{~K} / \mathrm{min}$ ). A single first order reaction model (Friedman) was used to calculate the kinetic parameters such as activation energy $\mathrm{E}$ and frequency factor $\mathrm{A}$. The research of this study may be utilized to increase the use of low rank coal, minimise wastages, pertaining the storage of Indian low rank coal.

\section{Materials and methods}

\subsection{Preparation of samples}

In this present research work all three coal sample 1,2 and 3 are low rank coal samples, collected from same coal mines (Eastern coal field limited) ranigunj, west-bengal,
India, which were listed in increasing order of their ash contents. The ash content increases 73.45, 75.71 and 79.45 for sample 1, 2 and 3 respectively. Collected coal samples were dried in sun light for 2-3 days. Dried coal samples were prepared in particle size range from $60 \mu \mathrm{m}$ to $70 \mu \mathrm{m}$.

\subsection{Proximate and ultimate analysis}

To justify the characterization of Indian low rank coal, the proximate analysis and ultimate analysis were carried out according to the procedures of the American Society for Testing and Materials (ASTM)-D 5373. Ultimate analysis of low rank coal samples were carried out on dry-base. The results for proximate/ultimate analysis of three kind of Indian low rank coal samples are shown in Tables 1 and 2.

\subsection{Experimental apparatus and procedures}

Pyrolysis experiments for all coal samples were carried out using NETZSCH (TG 209 F3 Tarsus) thermal analyser in nitrogen environment with a purge flow rate of $40 \mathrm{~mL} / \mathrm{min}$ at different heating rates of $50,100,150$ and $200 \mathrm{~K} / \mathrm{min}$ from ambient temperature to $950{ }^{\circ} \mathrm{C}$. In each experiment $10 \mathrm{mg}$ of low rank coal samples were placed on $\mathrm{Al}_{2} \mathrm{O}_{3}$ crucible.

\subsection{Kinetic analysis}

Kinetic studies of coal pyrolysis has an important role to design and operation of gasification plants. The kinetic analysis tests for low rank coal samples were carried out on NETZSCH thermal gravimetric analyser (TG 209 F3 Tarsus). The rate of reaction for a heterogeneous arhenius equation can be calculated as follows:

$\frac{\mathrm{d} \alpha}{\mathrm{d} t}=A e^{-\frac{E}{R T}} f(\alpha)$

In above Eq. (1), $\alpha$ shows the conversion degree, $T$ shows the reaction temperature, $t$ shows the time, $A$ shows the value for pre-exponential function, $R$ shows the value of ideal gas constant $(8.314 \mathrm{~J} / \mathrm{mol} \mathrm{K}), E$ shows the value of activation energy and $f(\alpha)$ means the function for reaction model. Basically $\alpha(T)$ indicate the combustion rate of fuel up to temperature $T$. Data obtained from TG analysis were

Table 1 Proximate analysis of Indian low rank coal

\begin{tabular}{lllllr}
\hline Indian low rank coal & $\mathrm{C}(\%)$ & $\mathrm{H}(\%)$ & $\mathrm{N}(\%)$ & $\mathrm{S}(\%)$ & $\mathrm{O}(\%)$ \\
\hline Sample 1 & 15.02 & 1.13 & 0.48 & 0.20 & 13.61 \\
Sample 2 & 17.10 & 1.30 & 0.54 & 0.21 & 14.02 \\
Sample 3 & 10.02 & 0.90 & 0.34 & 0.19 & 9.65 \\
\hline
\end{tabular}


Table 2 Ultimate analysis of Indian low rank coal (dry-basis)

\begin{tabular}{lllll}
\hline $\begin{array}{l}\text { Indian low rank } \\
\text { coal }\end{array}$ & $\begin{array}{l}\text { Volatile } \\
(\%)\end{array}$ & $\begin{array}{l}\text { Ash } \\
(\%)\end{array}$ & $\begin{array}{l}\text { Fixed carbon } \\
(\%)\end{array}$ & $\begin{array}{l}\text { Moisture } \\
(\%)\end{array}$ \\
\hline Sample-1 & 16.63 & 73.45 & 6.73 & 3.19 \\
Sample-2 & 14.81 & 75.71 & 7.03 & 2.45 \\
Sample-3 & 14.04 & 79.45 & 3.87 & 2.64 \\
\hline
\end{tabular}

utilized to evaluate the value for $\alpha(T)$ as shown in following equation.

$\alpha=\frac{m_{\mathrm{o}-m_{T}}}{m_{\mathrm{o}-m_{f}}}$

where $m_{\mathrm{o}}$ means mass of the coal sample at initial, $m_{T}$ is the mass of sample at temperature $T$ and $m_{f}$ is the final mass of the coal sample.

The function $f(\alpha)$ can be expressed as shown in Eq. (3).

$f(\alpha)=(1-\alpha)^{n}$

where, $n$ represent the order of reaction.

For a constant heating rate $\left(\beta=\frac{\mathrm{d} T}{\mathrm{~d} t}\right)$ in order to find out reaction rate as a function of temperature we can convert Eq. (1) into non isothermal experiment as shown in Eq. (4).

$\frac{d \alpha}{d T}=\frac{A}{\beta} e^{-\frac{E}{R T}} f(\alpha)$

Particularly, the activation energy for low rank coal is evaluated by Friedman method.

The expression for this Friedman analysis is as below-

$\ln \left(\beta \frac{\mathrm{d} \alpha}{\mathrm{d} T}\right)=\ln [A(f(\alpha))]-\frac{E_{a}}{R T}$

According to Eq. (5) the slop of $\ln \left(\beta \frac{\mathrm{d} \alpha}{\mathrm{d} T}\right)$ against $-\frac{1}{T}$ (K) can describe the value of activation energy related to low rank coal samples.

\section{Results and discussion}

\subsection{Characterization of the materials}

Tables 1 and 2 shows the composition characterization of Indian low rank coal. The proximate analysis shows that the volatile matter, fixed carbon, ash contents and moisture contents are in the range of $(14 \%-16 \%),(5 \%-8 \%),(73 \%-$ $79 \%)$ and $(2 \%-3 \%)$ respectively as listed in Table 1. Ultimate analysis shows that Indian low rank coal consists of moderate amount of carbon contents $(10 \%-15 \%)$ as shown in Table 2.

\subsection{TG profiles}

With TG analysis, the weight loss curves of coal samples under different pyrolysis circumstances can be achieved. From Figs. 1, 2, 3 and 4 shows the TGA profiles for three typical Indian low rank coal at four different heating 50, 100,150 and $200 \mathrm{~K} / \mathrm{min}$. The pyrolysis of low rank coal can be analysed in three stages. First stage is the removal of surface water or moisture, during this stage some depolymerisation conversion occurred. In this experiment discharging of moisture started from the temperature $100{ }^{\circ} \mathrm{C}$ to $180{ }^{\circ} \mathrm{C}$. Second stage is the reaction stage where $70 \%-$ $80 \%$ of weight losses. In third stage, the residue decomposed and the rate of weight loss becoming smaller, residue ratio also tends to be constant at the end as shown from Figs. 1, 2, 3 and 4 for heating rate 50, 100, 150 and $200 \mathrm{~K} /$ min respectively. It is clearly shows that the weight loss of coal sample as volatile matter gets released from $200{ }^{\circ} \mathrm{C}$ to $450{ }^{\circ} \mathrm{C}$. The TG curves moves to the higher temperature zone with increasing the heating rate. The thermal events for all three low rank coal samples are same. The only difference is the using different heating rates in different TGA tests. The devolatilization phase started from $200{ }^{\circ} \mathrm{C}$ up to temperature range $500{ }^{\circ} \mathrm{C}$. After the temperature $500{ }^{\circ} \mathrm{C}$ process started for discharging the solid residue from samples. The major devolatilization is takes place from the temperature range $200{ }^{\circ} \mathrm{C}$ to $600{ }^{\circ} \mathrm{C}$ which is known as the zone for active pyrolysis as shown from Figs. 1, 2, 3 and 4.

Mostly it is observed that in TGA, the final solid residue weight increases with increasing the sample weight. In active pyrolysis zone, the pyrolysis process gets enhanced to form a solid residue (charcoal) and volatile content comes down quite dramatically. Basically devolatilization does not occur after the temperature range $600{ }^{\circ} \mathrm{C}$. The zone where is no further weight loss is known as passive zone. In this zone yet carbon and ash were formed as the final solid residue. In this experiment fast pyrolysis of low rank coal takes place in the temperature range of approximately $300-600{ }^{\circ} \mathrm{C}, \quad 350-600{ }^{\circ} \mathrm{C}, \quad 400-650{ }^{\circ} \mathrm{C}$ and $450-750{ }^{\circ} \mathrm{C}$ for the heating rate $50,100,150$ and $200 \mathrm{~K} /$ min respectively.

\subsection{DTG Profiles}

The maximum rate of weight loss which occurs at the peak temperature can be identified in the DTG curves. From Figs. 5, 6, 7 and 8 explaining about temperature and derivative of TG curves for low rank coal samples at heating rates $(50,100,150,200 \mathrm{~K} / \mathrm{min}$.). With increasing the heating rate, reaction region and peak point of pyrolysis rate moves to higher temperature. The maximum weight loss of sample takes place at the highest value of 


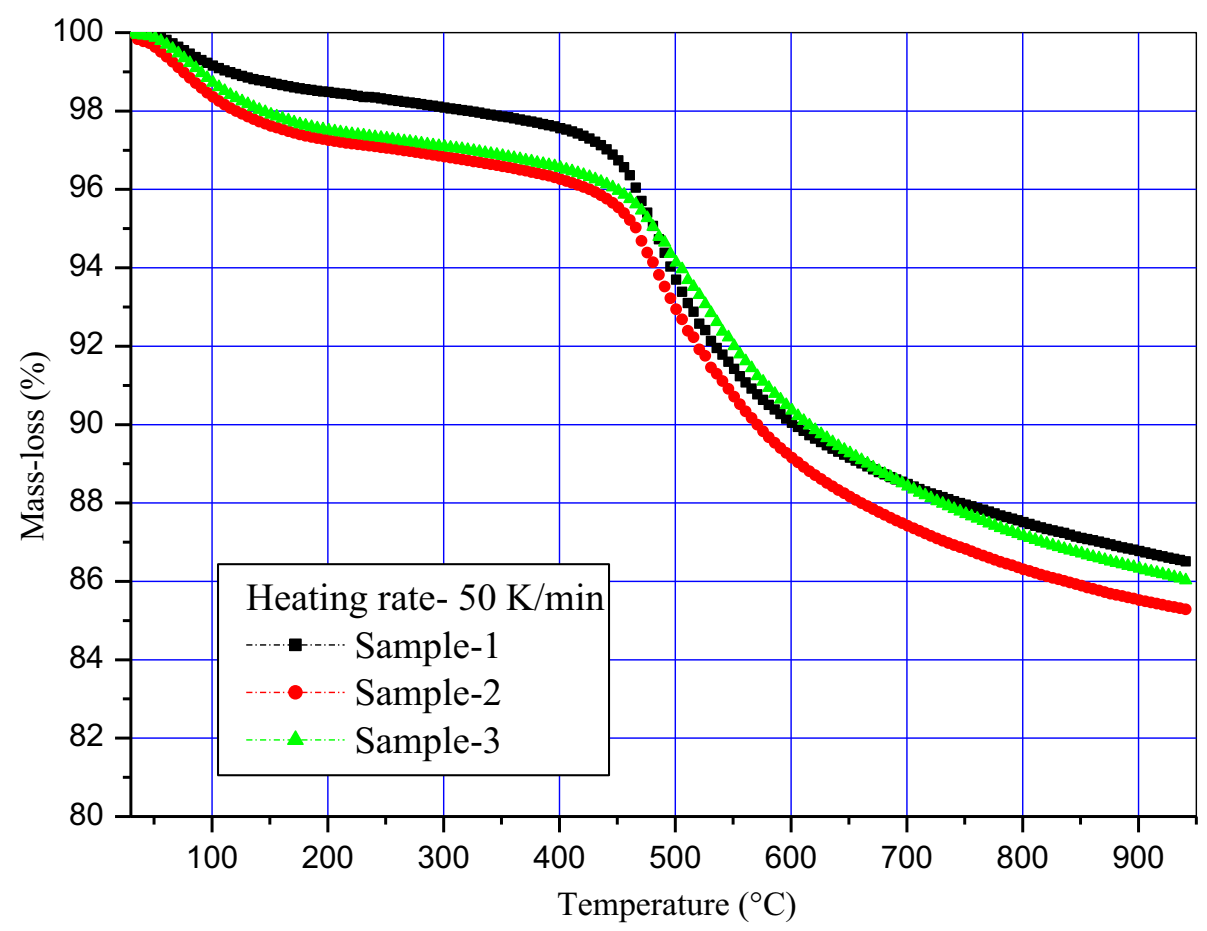

Fig. 1 TG curves for low rank coal at heating rate $50 \mathrm{~K} / \mathrm{min}$

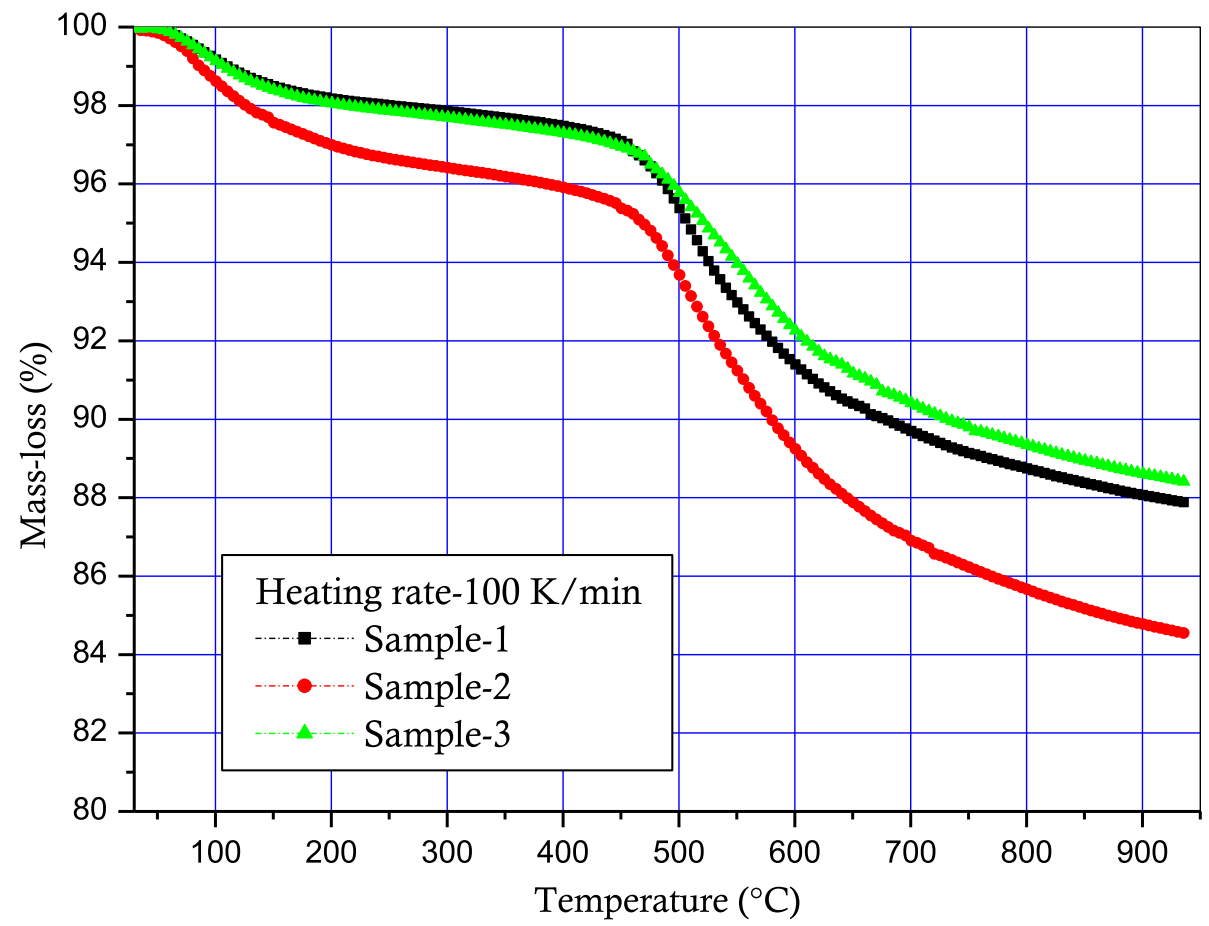

Fig. 2 TG curves for low rank coal at heating rate $100 \mathrm{~K} / \mathrm{min}$

temperature that is known as the peak value on the DTG curves. Final solid residue for low rank coal reduces with increasing the heating rate. It shows that for lower heating rate we can get higher solid residue (\%). In this experiment the maximum weight loss for heating rate 50,100, 150 and
$200 \mathrm{~K} / \mathrm{min}$ is taking place on $440,460,510$ and $560{ }^{\circ} \mathrm{C}$ respectively. Thermal decomposition of coal sample get started at above $150{ }^{\circ} \mathrm{C}$ but not completed even at $900{ }^{\circ} \mathrm{C}$ due to the composition of low rank coal samples. Hence the low rank coal samples need to be heated up to $950{ }^{\circ} \mathrm{C}$ to 


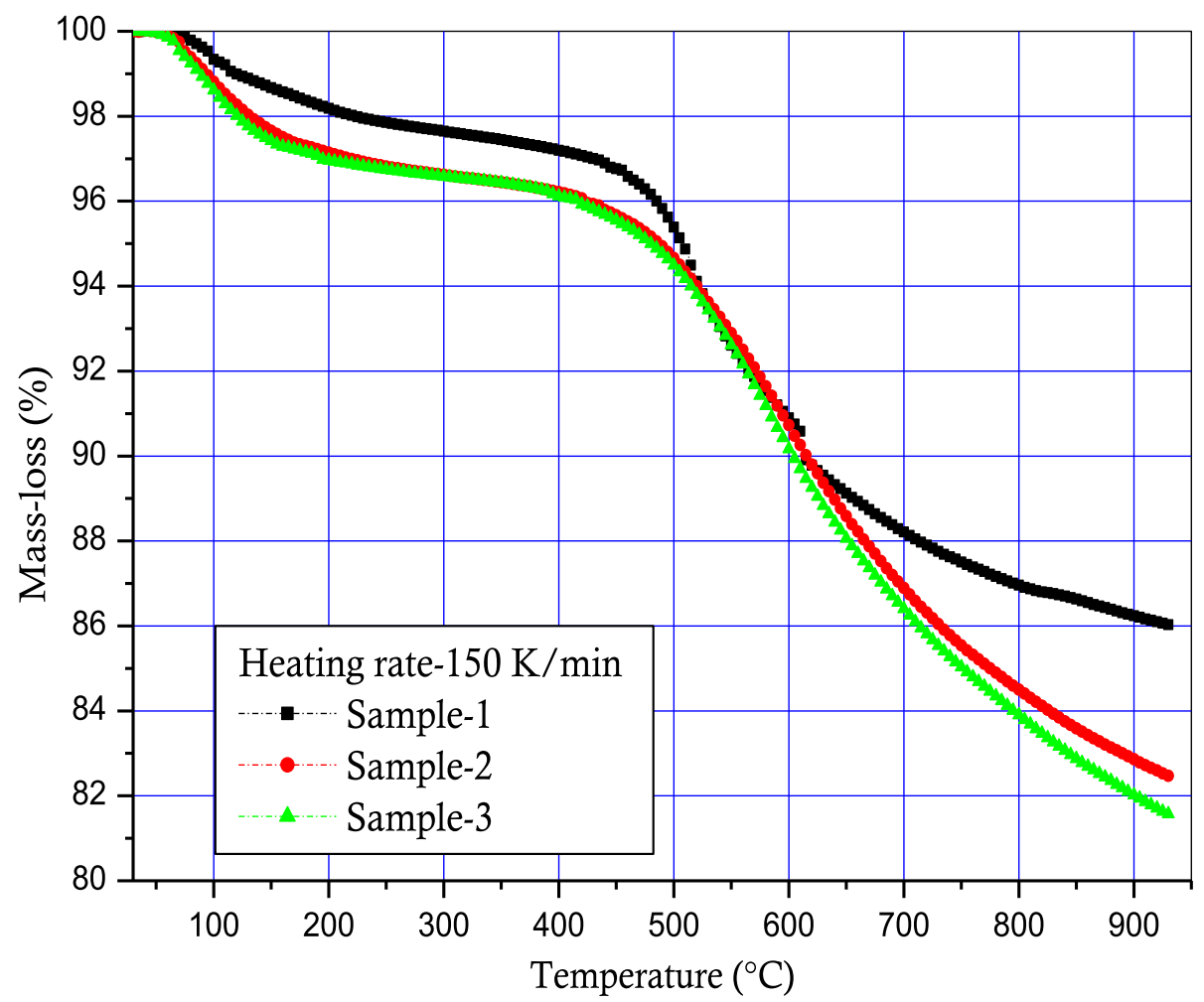

Fig. 3 TG curves for low rank coal at heating rate $150 \mathrm{~K} / \mathrm{min}$

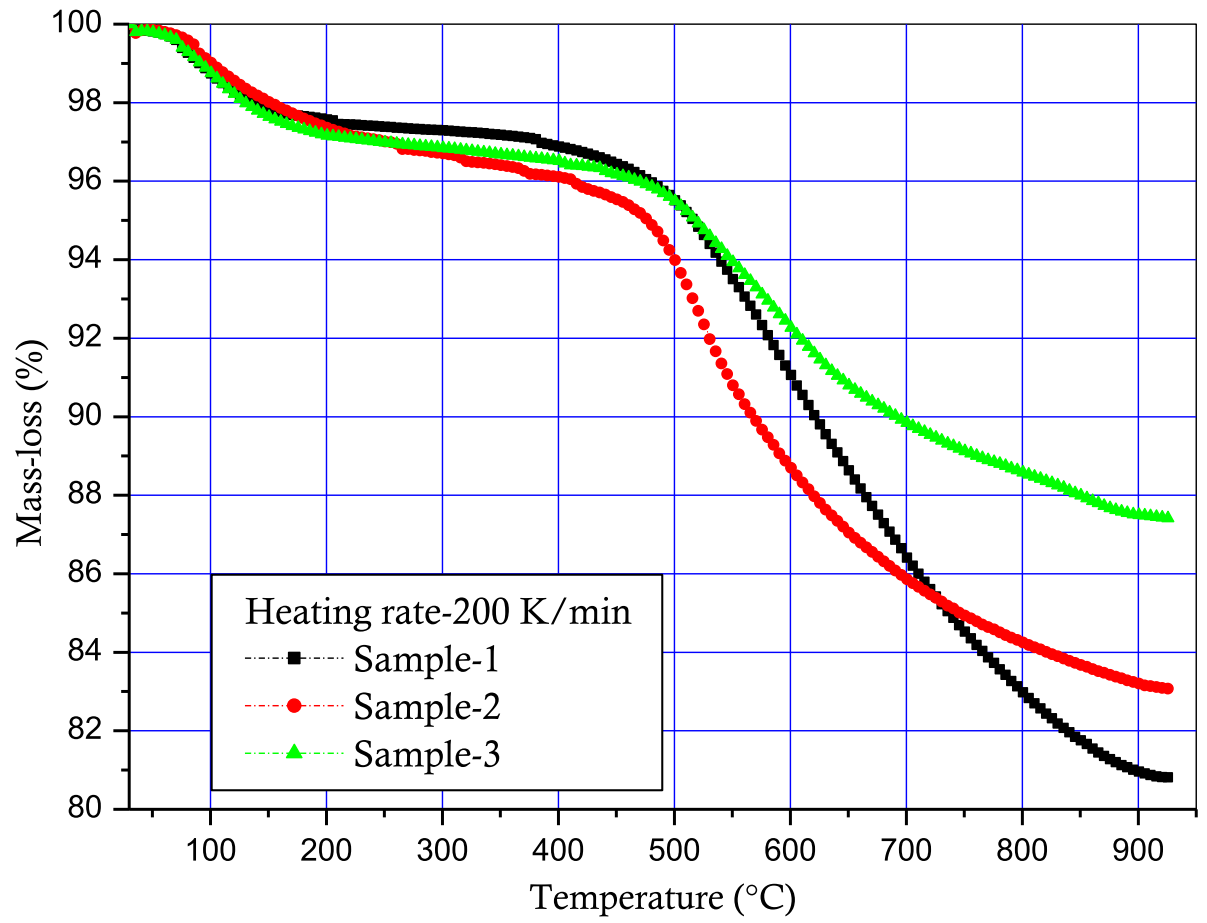

Fig. 4 TG curves for low rank coal at heating rate $200 \mathrm{~K} / \mathrm{min}$

remove all volatiles and carbon. During the pyrolysis the final obtained weight of residue under isothermal condition is the result of both the releases of volatile from the samples and the partial oxidation of sample's material. Table 3 shows the temperature range where maximum weight loss at four different heating rate $(50,100,150$ and 


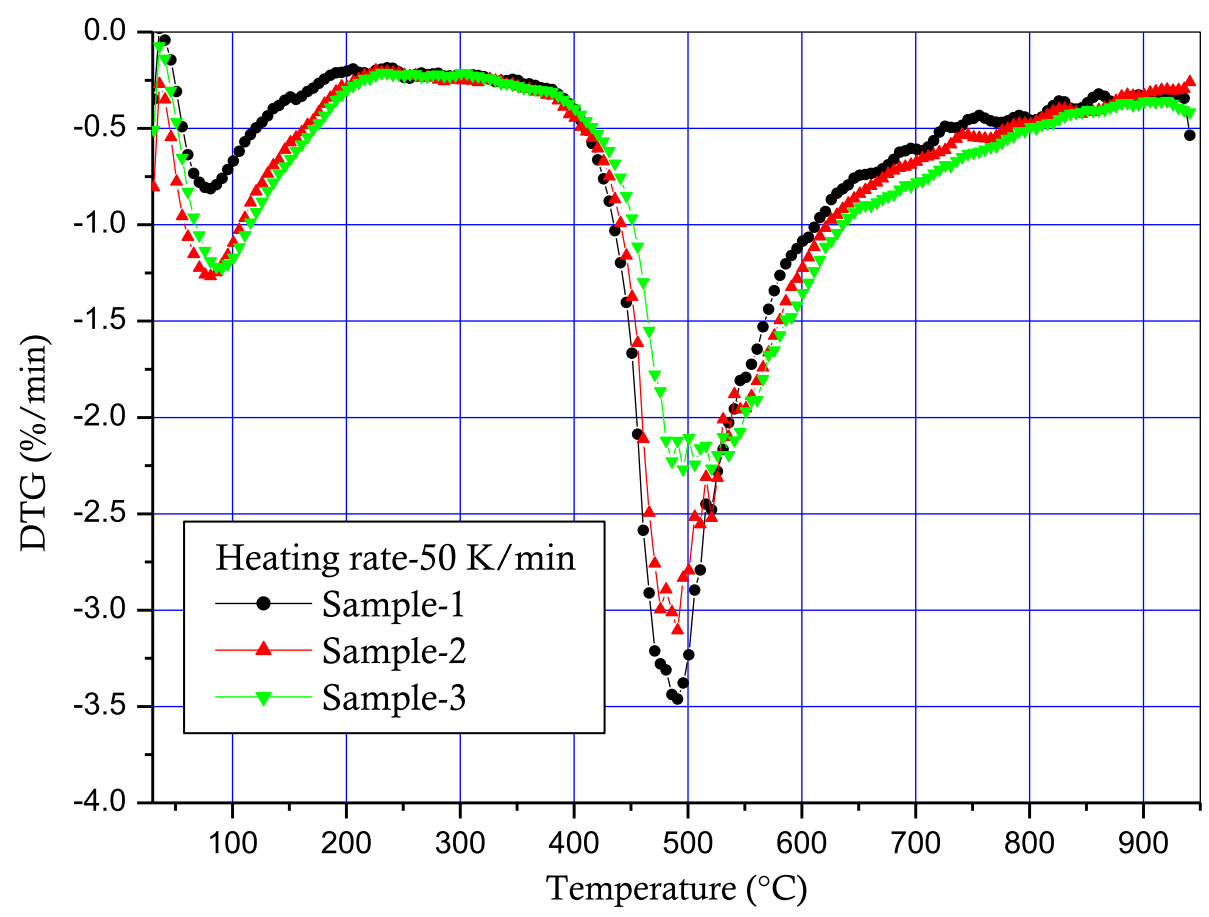

Fig. 5 DTG curves for low rank coal at heating rate $50 \mathrm{~K} / \mathrm{min}$

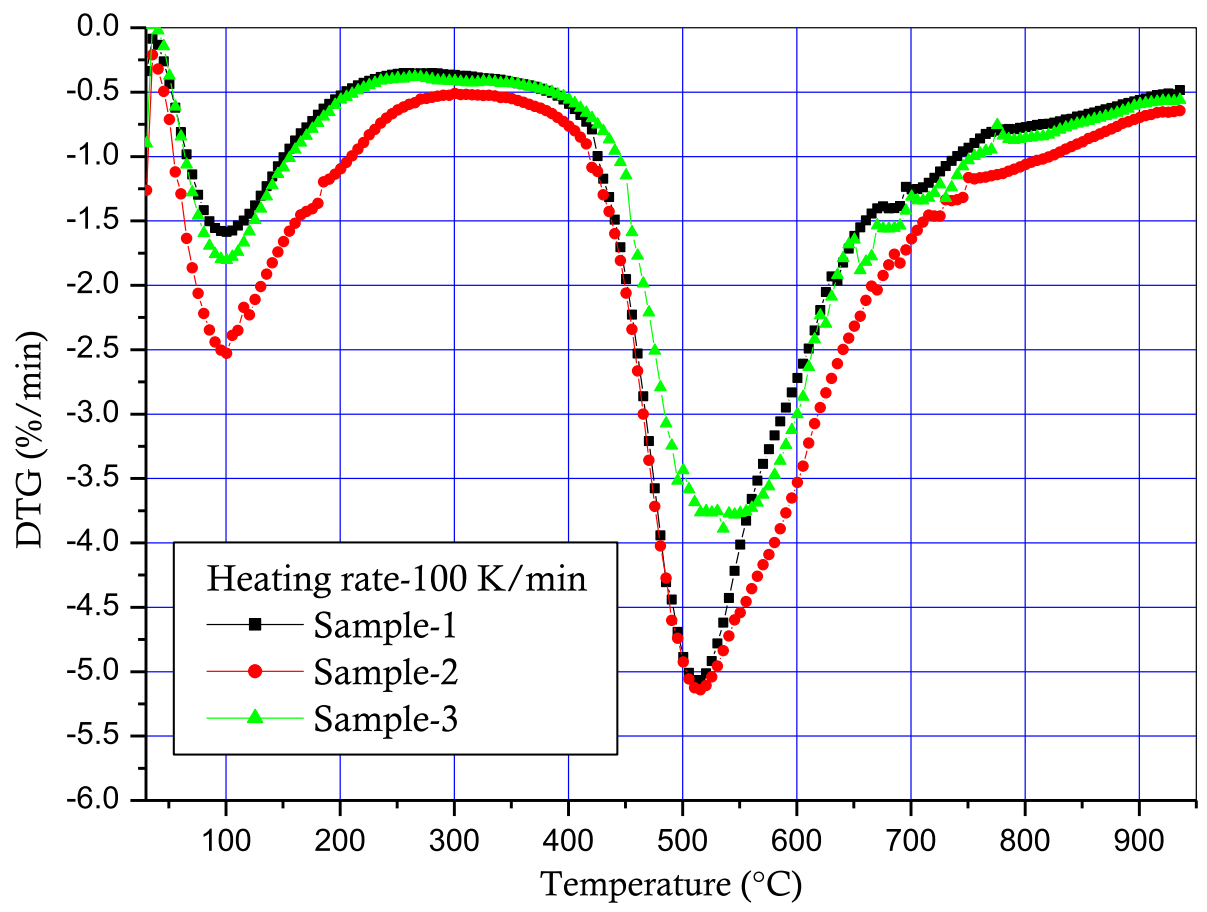

Fig. 6 DTG curves for low rank coal at heating rate $100 \mathrm{~K} / \mathrm{min}$

$200 \mathrm{~K} / \mathrm{min}$.). During the decomposition, weight loss (\%) of coal samples decreases from $11 \%$ to $6 \%$ for the temperature range $410-590{ }^{\circ} \mathrm{C}$. Table 3 shows the influence of heating rate on weight loss and residual mass of samples.

The final solid residue of low rank coal decreases with increasing the heating rate. Table 3 shows that lower heating rate can obtain higher solid residue. The present experimental data shows that the final yield of solid residue for low rank coal at heating rate 50, 100, 150 and $200 \mathrm{~K} /$ $\min$ is $76.28 \%, 71.87 \%, 65.98 \%$ and $61.01 \%$ respectively. 


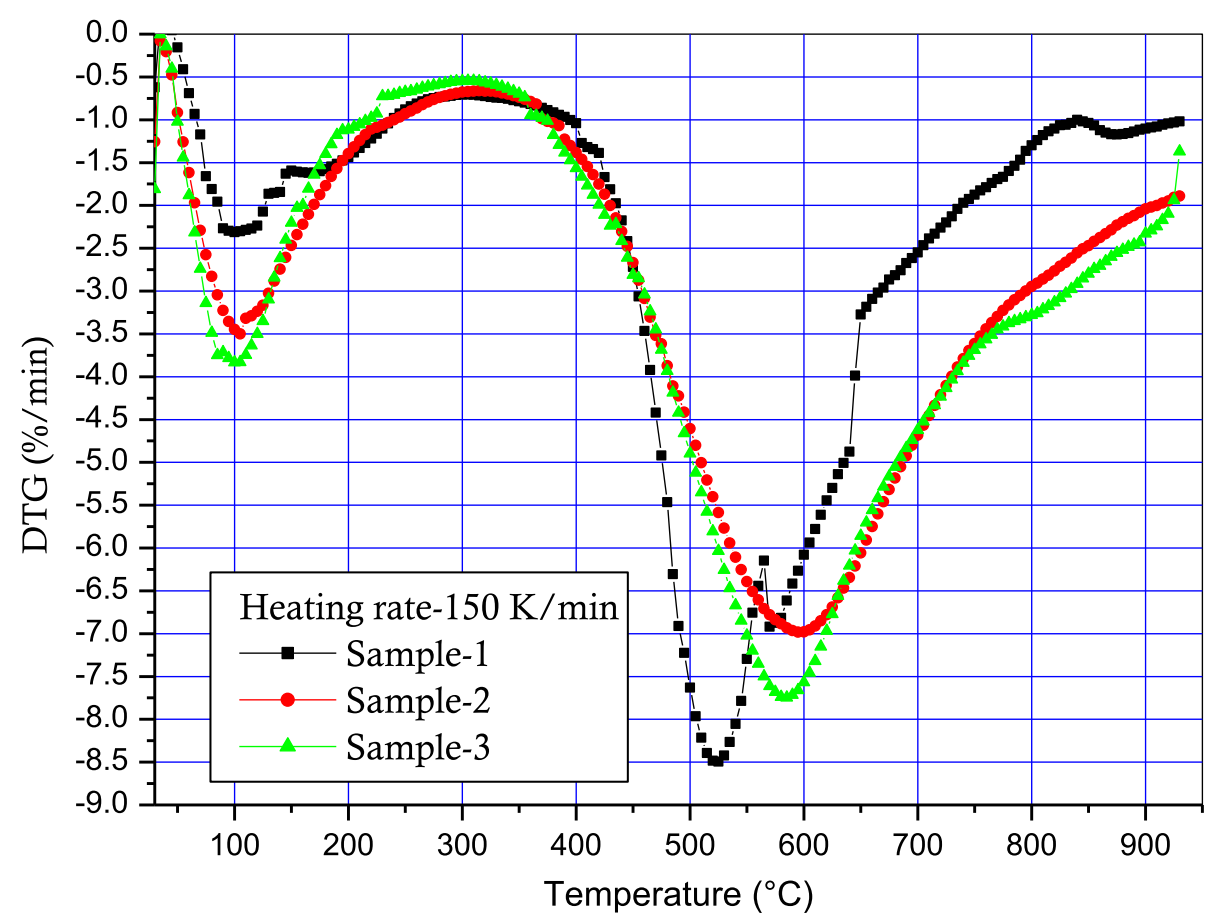

Fig. 7 DTG curves for low rank coal at heating rate $150 \mathrm{~K} / \mathrm{min}$

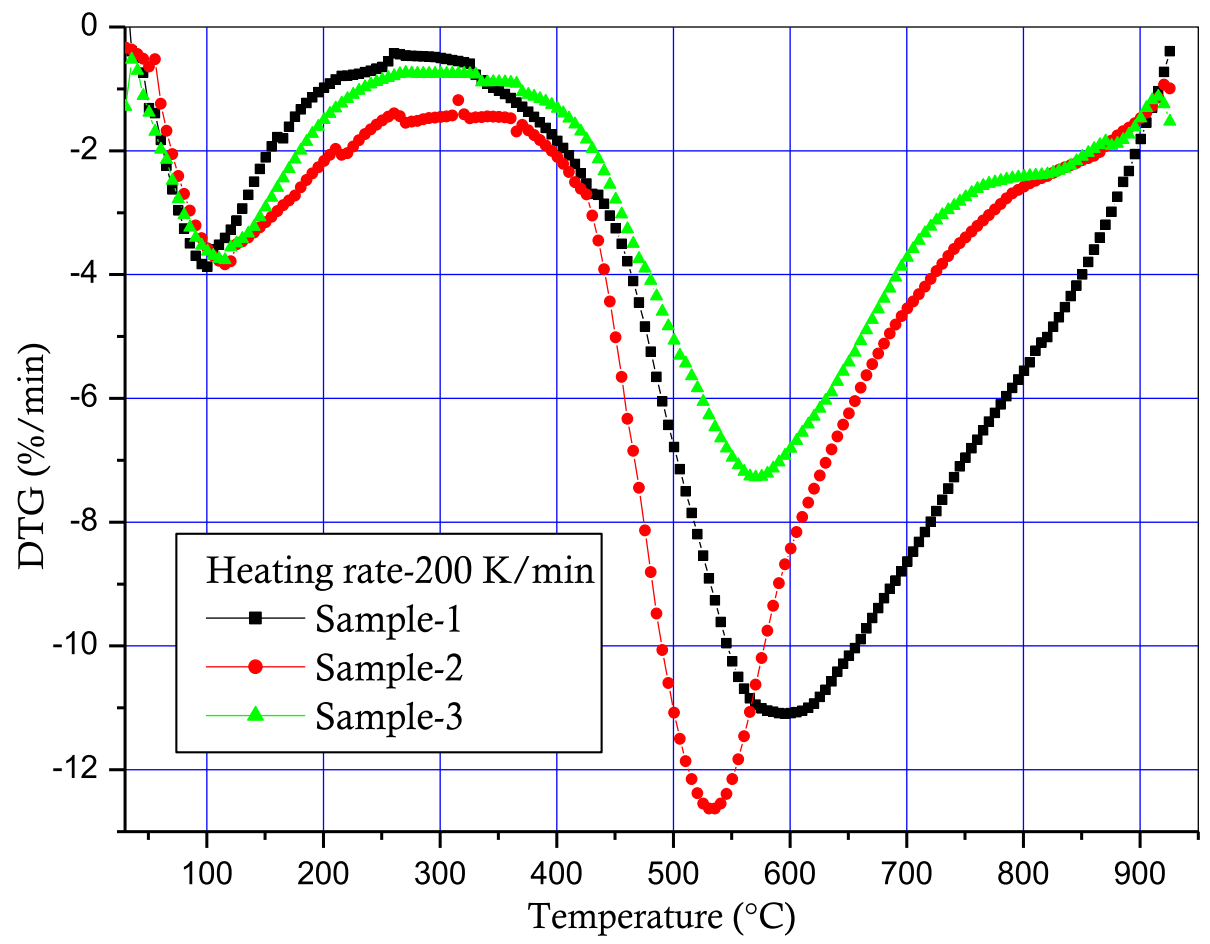

Fig. 8 DTG curves for low rank coal at heating rate $200 \mathrm{~K} / \mathrm{min}$

\subsection{Effect of the heating rate}

Normally the heating rate affects the peak of the TGA curves, location of the maximum temperature and maximum decomposition rate respectively as shown in Table 4.
Effect of heating rate on coal pyrolysis process can be realized with TG and DTG curves as shown in Figs. 9 and 10. The start and end temperature of coal increases with increasing the heating rate and maximum weight loss point also increases as shown in Fig. 10. This may be due to 
Table 3 Temperature range for maximum weight loss of coal samples with weight loss $(\%)$ and residual mass at heating rates (50, $100,150,200 \mathrm{~K} / \mathrm{min}$ ) in nitrogen atmospheres

\begin{tabular}{llll}
\hline $\begin{array}{l}\text { Heating } \\
\text { rate }(\mathrm{K} / \\
\text { min) }\end{array}$ & $\begin{array}{l}\text { Temperature range for } \\
\text { maximum weight loss } \\
\left({ }^{\circ} \mathrm{C}\right)\end{array}$ & $\begin{array}{l}\text { Weight loss of } \\
\text { sample (wt } \%)\end{array}$ & $\begin{array}{l}\text { Residual } \\
\text { mass } \\
(\%)\end{array}$ \\
\hline 50 & $410-679$ & 11.02 & 76.28 \\
100 & $448-676$ & 10.04 & 71.87 \\
150 & $432-615$ & 14.25 & 65.98 \\
200 & $422-590$ & 16.85 & 61.01 \\
\hline
\end{tabular}

Table 4 Characteristics temperature in TG/DTG curves of low rank coal at different heating rate

\begin{tabular}{lllllll}
\hline $\begin{array}{l}\text { Heating rate }(\mathrm{K} / \\
\text { min })\end{array}$ & $\begin{array}{l}T_{\mathrm{c}} \\
\left({ }^{\circ} \mathrm{C}\right)\end{array}$ & $\begin{array}{l}T_{\mathrm{i}} \\
\left({ }^{\circ} \mathrm{C}\right)\end{array}$ & $\begin{array}{l}T_{\mathrm{m}} \\
\left({ }^{\circ} \mathrm{C}\right)\end{array}$ & $\begin{array}{l}T_{\max } \\
\left({ }^{\circ} \mathrm{C}\right)\end{array}$ & $\begin{array}{l}T_{\mathrm{n}} \\
\left({ }^{\circ} \mathrm{C}\right)\end{array}$ & $\begin{array}{l}T_{\mathrm{f}} \\
\left({ }^{\circ} \mathrm{C}\right)\end{array}$ \\
\hline 50 & 97 & 180 & 370 & 500 & 630 & 850 \\
100 & 96 & 184 & 384 & 510 & 700 & 870 \\
150 & 97 & 178 & 390 & 550 & 710 & 900 \\
200 & 98 & 190 & 394 & 580 & 750 & 910 \\
\hline
\end{tabular}

thermal leg effect on coal pyrolysis. As above Table 3 shows the relatively parameter at different heating rates. During the coal pyrolysis the weight loss curves under different heating rates are parallel, which shows that there is a similar reaction mechanism and it is affected only by reaction temperature. In this experiments the peak temperature were found $500,510,550$ and $580{ }^{\circ} \mathrm{C}$ for the heating rate $50,100,150$ and $200 \mathrm{~K} / \mathrm{min}$ respectively as shown in Table 4. So from present analysis it can be observed that, when the heating rate increases, peak and finish temperature of low rank coal pyrolysis also increases. The weight loss of coal sample varies with $51.06 \%$ to $57.54 \%$ at lower heating rates but the weight loss increases at higher heating rates.

Table 4 shows the temperature characteristics of TG and DTG curves of low rank coal at different heating rates (50, 100,150 and $200 \mathrm{~K} / \mathrm{min}$ ) where $T_{\mathrm{c}}=$ Peak temperature for moisture loss, $T_{\mathrm{i}}=$ Initial temperature of pyrolysis, $T_{\mathrm{m}-}$ $=$ Initial temperature for fast pyrolysis, $T_{\max }=$ Largest peak temperature of pyrolysis, $T_{\mathrm{n}}=$ Finish temperature of fast pyrolysis, $T_{\mathrm{f}}=$ Pyrolysis end temperature .

\subsection{Evaluation of kinetic parameters}

The kinetic parameters for pyrolysis of Indian low rank coal were obtained by iso- conversional model free method known as Friedman method under nitrogen atmosphere by using the TGA curves at four different heating rates. This model free analysis is applied as first order reaction kinetics. Thus a plot of $\ln \left(\beta \frac{\mathrm{d} \alpha}{\mathrm{d} T}\right)$ against $-\frac{1}{T}(\mathrm{~K})$, should result in a straight line. The average value of activation energy of Indian low rank coal samples are in the range

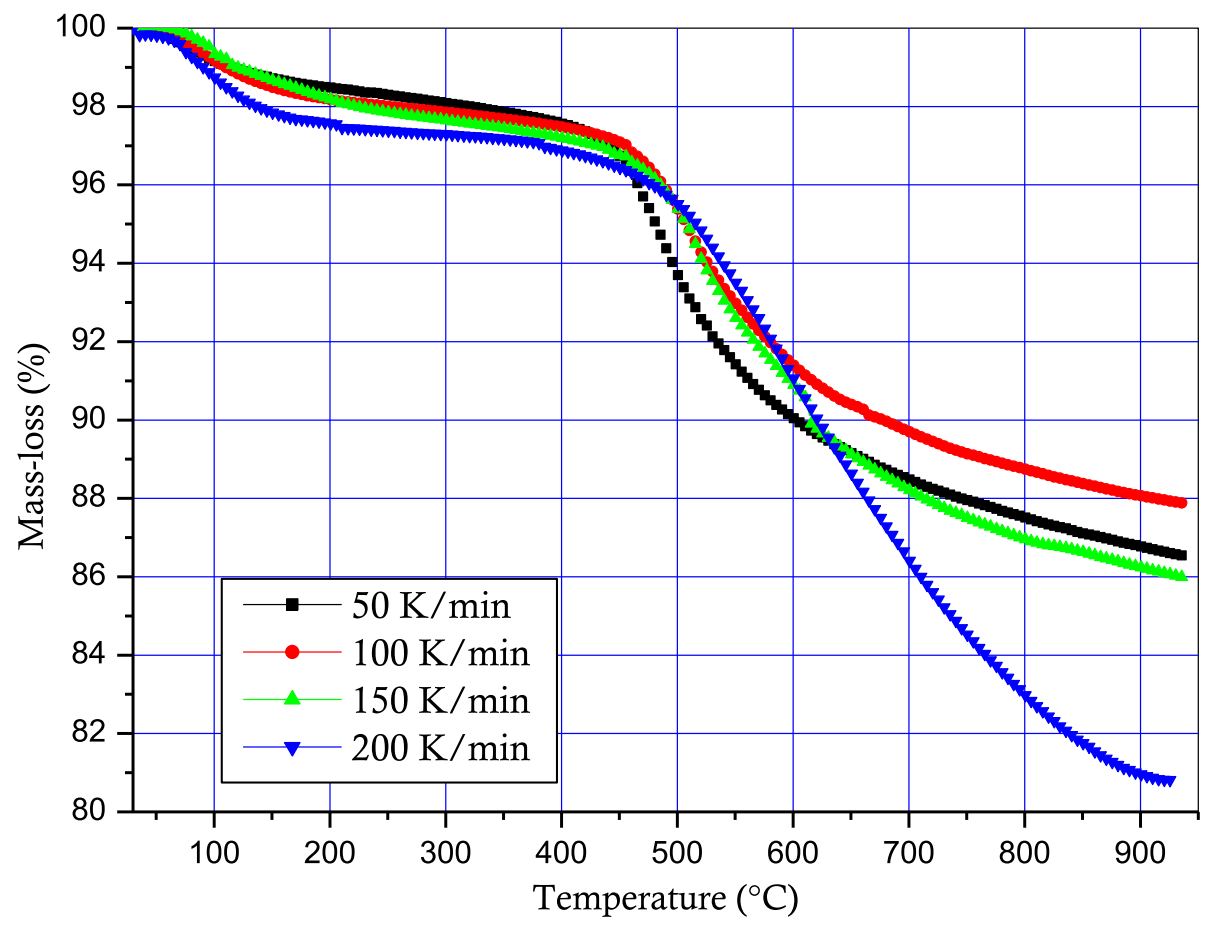

Fig. 9 TG curves at different heating rates on low rank coal pyrolysis process 


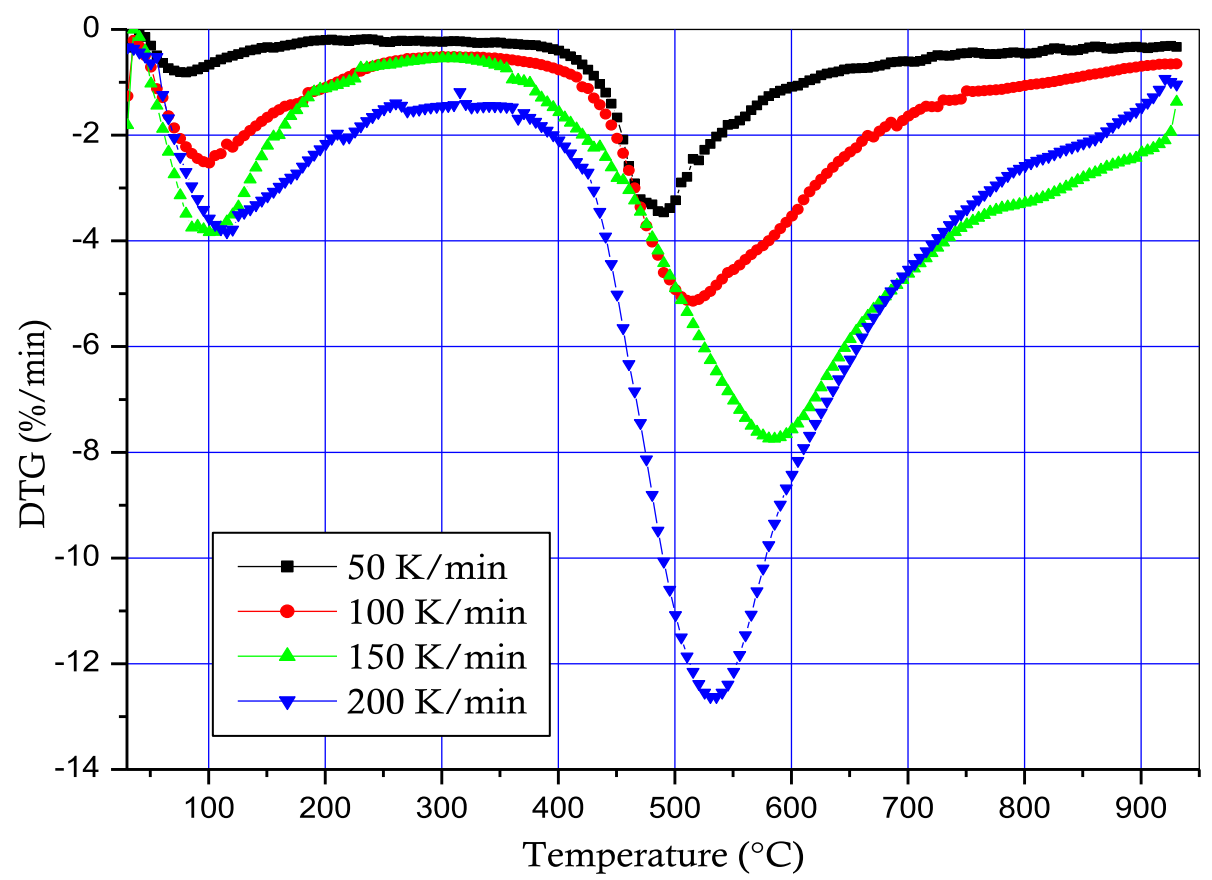

Fig. 10 DTG curves at different heating rate on low rank coal pyrolysis process

$49.312 \mathrm{~kJ} / \mathrm{mol}$. The activation energy and frequency factor estimated for the coal samples were listed in Table 5. It shows that the obtained results from TGA were in line for the given value of conversion degree $(\alpha)$ from 0.20 to 0.85 . The mean correlation coefficient $\left(R^{2}\right)$ values were found to be greater than 0.985 as shown in Table 6 . The results obtained from Friedman method was in good agreement with a deviation below 1\%. Figure 11 describes the range of activation energy with respect to conversion rate $(\alpha)$.

During the pyrolysis, when heating rate increases, value for activation energy of low rank coal also continuously decreases, because energy is supplied by supporting fuel with high heating rate. Huijuan et al. (2016) reported the value of activation energy for different category of low rank coal samples (Ningxia Province of China) during the combustion process in the range of $373 \mathrm{~kJ} / \mathrm{mol}$. Buratti et al. (2015) reported relatively $41.10 \mathrm{~kJ} / \mathrm{mol}$ of activation energy for Indonesian subbituminous coal. Yunfei Wang et al. (2016) reported an activation energy value of

Table 5 Pyrolysis kinetic parameters of low rank coal

\begin{tabular}{llll}
\hline $\begin{array}{l}\text { Heating } \\
\text { rate }(\mathrm{K} / \\
\mathrm{min})\end{array}$ & $\begin{array}{l}\text { Mean value of } \\
\text { activation Energy }\left(E_{\mathrm{a}}\right) \\
(\mathrm{kJ} / \mathrm{mol})\end{array}$ & $\begin{array}{l}\text { Pre- } \\
\text { exponential } \\
\text { factor } A\left(\mathrm{~S}^{-1}\right)\end{array}$ & $\begin{array}{l}\text { Fraction mass } \\
\text { loss } \\
(\text { Average })\end{array}$ \\
\hline 50 & 56.142 & 3.1405 & 0.98 \\
100 & 50.376 & 3.096 & 0.96 \\
150 & 46.536 & 3.1563 & 0.98 \\
200 & 44.194 & 3.1982 & 0.97 \\
\hline
\end{tabular}

Table 6 Value of Coefficient of determination (R-Square) with conversion degree $(\alpha)$ and activation energy $\left(E_{\mathrm{a}}\right)$

\begin{tabular}{lll}
\hline Conversion degree $(\alpha)$ & $\left(E_{\mathrm{a}}\right)(\mathrm{kJ} / \mathrm{mol})$ & $R^{2}$ \\
\hline 0.20 & 46.142 & 0.997 \\
0.25 & 45.376 & 0.998 \\
0.30 & 45.136 & 0.996 \\
0.35 & 45.114 & 0.999 \\
0.40 & 46.552 & 0.999 \\
0.45 & 48.114 & 0.999 \\
0.50 & 50.112 & 0.998 \\
0.55 & 50.232 & 0.998 \\
0.60 & 52.881 & 0.997 \\
0.65 & 53.121 & 0.993 \\
0.70 & 56.424 & 0.996 \\
0.75 & 57.127 & 0.997 \\
0.80 & 63.181 & 0.997 \\
0.85 & 64.851 & 0.997 \\
Average & 51.740 & 0.997 \\
\hline
\end{tabular}

$50.56 \mathrm{~kJ} / \mathrm{mol}$ for Chinese Shenhua raw Coal. Table 7 shows the comparison of activation energy for Indian low rank coal with other countries low rank coal samples. 


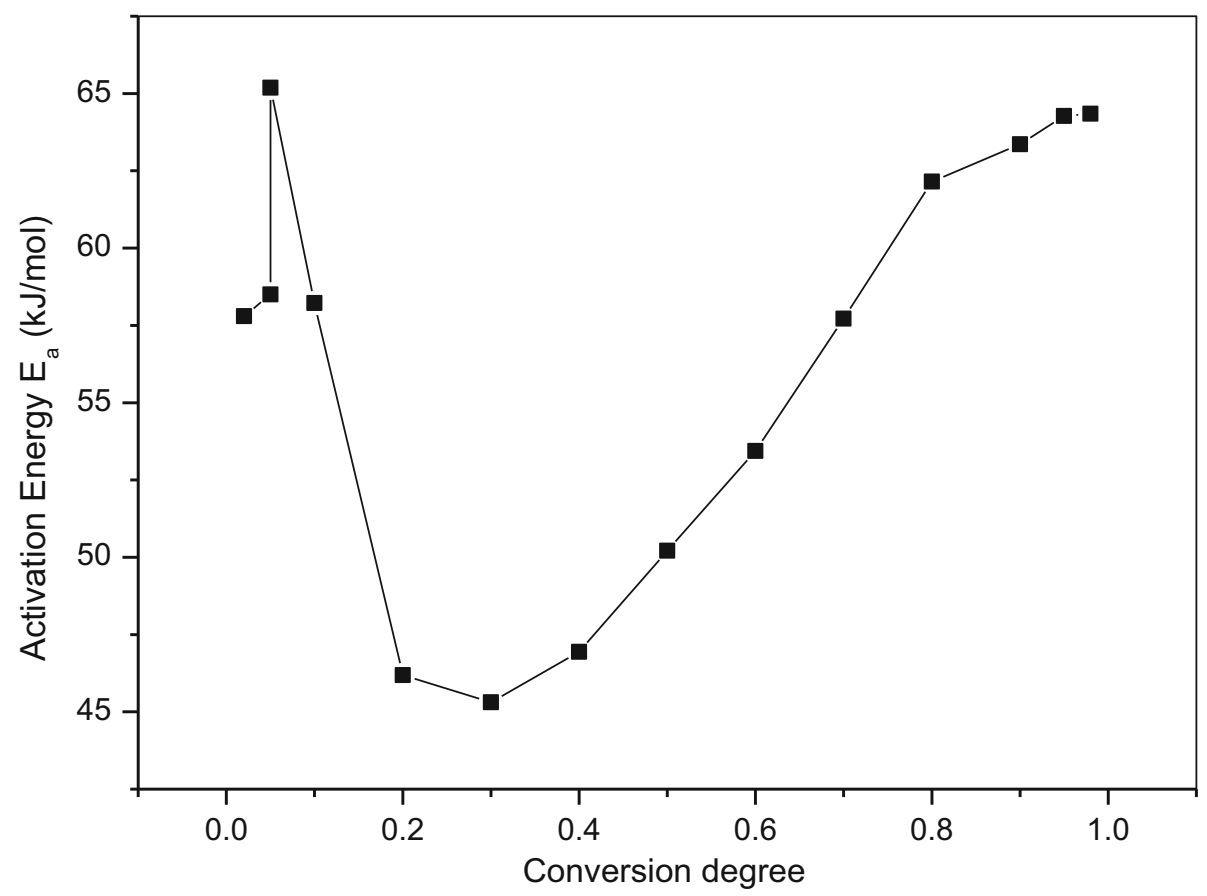

Fig. 11 Activation energy with function of conversion using the Friedman analysis

Table 7 Activation energy for Indian low rank coal compared with other low rank coal samples

\begin{tabular}{llll}
\hline Different low rank coal sample & Heating rate $(\mathrm{K} / \mathrm{min})$ & Mean value of activation energy (kJ/mol) & References \\
\hline Indian low rank coal & $50,100,150,200$ & 49.312 & Present study \\
Waste coal (Ningxia Province of China) & 373 & 69.13 & Song et al. (2016) \\
Indonesian subbituminous Coal & $278,283,288,293$ & 41.10 & Buratti et al. (2015) \\
Chinese Shenhua Raw Coal & $283,288,293$ & 50.56 & Yunfei Wang et al. (2016) \\
Low rank Malaysian coal & $283,293,303,313$ & 266.6 & Idris et al. (2010) \\
\hline
\end{tabular}

\section{Conclusions}

Thermal behaviour of Indian low rank coal and its pyrolysis have been investigated using TGA. The effect of the heating rate on the kinetic process during pyrolysis of Indian low rank coal also investigated. Evidently, the three typical Indian low rank coal samples shows distinct behaviour upon pyrolysis. Reaction starts with low heating rate when coal is pyrolysed in nitrogen atmosphere. Kinetic parameters of coal pyrolysis such as activation energy, preexponential factor etc. were determined based on TGA data by using model free analysis known as Friedman method. The activation energy were estimated as $49.312 \mathrm{~kJ} / \mathrm{mol}$ (mean value). The study reveals that low rank Indian coal can be used for power generation and industrial boiler operation. The pyrolysis process of low rank coal basically involves breaking different chemical bonds with different energies. From the current study it is clear that Indian low rank coal is a kind of valuable resources for power generation.

Acknowledgements Authors are thankful to Director, CSIR-CMERI, Durgapur and Director-NIT, Durgapur for their support to carry out this research work.

Open Access This article is distributed under the terms of the Creative Commons Attribution 4.0 International License (http://crea tivecommons.org/licenses/by/4.0/), which permits unrestricted use, distribution, and reproduction in any medium, provided you give appropriate credit to the original author(s) and the source, provide a link to the Creative Commons license, and indicate if changes were made.

\section{References}

Bach QV, Chen WH (2017) Pyrolysis characteristics and kinetics of microalgae via thermogravimetric analysis (TGA): a state-of the art review. Bioresour Technol. https://doi.org/10.1016/j.biortech. 2017.06.087 
Buratti C, Barbanera M, Bartocci P, Fantozzi F (2015) Thermogravimetric analysis of the behavior of sub-bituminous coal and cellulosic ethanol residue during co-combustion. Bioresour Technol 186:154-162. https://doi.org/10.1016/j.biortech.2015. 03.041

Cai J, Wang Y, Zhoua L, Huang Q (2008) Thermogravimetric analysis and kinetics of coal/plastic blends during co-pyrolysis in nitrogen atmosphere. Fuel Process Technol 89:21-27. https://doi. org/10.1016/j.fuproc.2007.06.006

Chandrasekaran A, Ramachandran S, Subbiah S (2017) Determination of kinetic parameters in the pyrolysis operation and thermal behavior of prosopis juliflora using Thermogravimetric Analysis. Bioresour Technol. https://doi.org/10.1016/j.biortech.2017.02. 119

Cheng Y, Yan B, Li T, Li X, Guo CY (2015) Experimental study on coal tar pyrolysis in thermal plasma. Plasma Chem Plasma Process 35:401-413. https://doi.org/10.1007/s11090-014-9608-3

Cor J, Manton N, Mul G, Eckstrom D, Olson W, Malhotra R (2000) An experimental facility for the study of coal pyrolysis at 10 atmospheres. Energy Fuels 14:692-700. https://doi.org/10.1021/ ef9902348

Duan W, Yu Q, Liu J, Wu T, Yang F, Qin Q (2016) Experimental and kinetic Study of steam gasification of low-rank coal in molten blast furnace slag. Energy 111:859-868. https://doi.org/10.1016/ j.energy.2016.06.052

Duan W, Yu Q, Liu J, Wu T, Yang F, Qin Q (2017) Pyrolysis of coal by solid Heat carrier-experimental study and kinetic modelling. Energy 1:1. https://doi.org/10.1016/j.energy.2017.06.132

Feng S, Li P, Liu Z, Zhang Y, Li Z (2016) Experimental study on pyrolysis characteristic of coking coal from Ningdong coalfield. J Energy Inst 91:233-239. https://doi.org/10.1016/j.joei.2016.12. 001

Ferrara F, Orsini A, Plaisant A, Pettinau A (2014) Pyrolysis of coal, biomass and their blends: performance assessment by thermogravimetric analysis. Bioresour Technol 171:433-441. https:// doi.org/10.1016/j.biortech.2014.08.104

Gao Z, Zheng M, Zhang D, Zhang W (2015) Low temperature pyrolysis properties and kinetics of non-coking coal in Chinese western coals. J Energy Inst. https://doi.org/10.1016/j.joei.2015. 07.002

Geng C, Li S, Yue C, Ma Y (2015) Pyrolysis characteristics of bituminous coal. J Energy Inst 89:725-730. https://doi.org/10. 1016/j.joei.2015.04.004

Idris SS, Rahman NA, Ismail K, Alias AB, Rashid ZA, Aris MJ (2010) Investigation on thermochemical behaviour of low rank Malaysian coal, oil palm biomass and their blends during pyrolysis via thermogravimetric analysis (TGA). Bioresour Technol 101:4584-4592. https://doi.org/10.1016/j.biortech. 2010.01.059
Idris SS, Rahman NA, Ismail K (2012) Combustion characteristics of Malaysian Oil palm biomass, sub-bituminous coal and their respective blends via thermogravimetric analysis (TGA). Bioresour Technol 123:581-591. https://doi.org/10.1016/j.biortech. 2012.07.065

Jain A, Mehra A, Ranade V (2016) Processing of TGA data: analysis of iso-conversional and model fitting methods. Fuel 165:490-498. https://doi.org/10.1016/j.fuel.2015.10.042

Jayaraman K, Gokalp I, Jeyakumar S (2017a) Estimation of synergetic effects of $\mathrm{CO} 2$ in high ash coal-char steam gasification. App Therm Eng 110:991-998

Jayaraman K, Kok MV, Gokalp I (2017b) Thermogravimetric and mass spectrometric (TG-MS) analysis and kinetics of coalbiomass blends. Renew Energy 101:293-300

Jayaraman K, Kok MV, Gokalp I (2017c) Pyrolysis, combustion and gasification studies of different sized coal particles using TGAMS. Appl Therm Eng 125:1446-1455. https://doi.org/10.1016/j. applthermaleng.2017.07.128

Kajitani S, Suzuki N, Ashizawa M, Hara S (2006) $\mathrm{CO}_{2}$ gasification rate analysis of coal char in entrained flow coal gasifier. Fuel 85:163-169. https://doi.org/10.1016/j.fuel.2005.07.024

Kelebopile L, Sun R, Liao J (2011) Fly ash and coal char reactivity from thermo-gravimetric (TGA) experiments. Fuel Process Technol 92:1178-1186. https://doi.org/10.1016/j.fuproc.2011. 01.007

Li B, Chen G, Zhang H, Sheng C (2014) Development of nonisothermal TGA-DSC for kinetics analysis of low temperature coal oxidation prior to ignition. Fuel 118:385-391. https://doi. org/10.1016/j.fuel.2013.11.011

Li B, Li X, Li W, Li JB, Li X, Feng J (2017) Co-pyrolysis performance of coal and its direct coal liquefaction residue with solid heat carrier. Fuel Process Technol 166:69-76. https://doi. org/10.1016/j.fuproc.2017.05.030

Naveen C, Premalatha M (2014) Thermo gravimetric and kinetic studies on dried solid waste of post-methanated distillery effluent under oxygen and nitrogen atmosphere. Bioresour Technol 174:126-133. https://doi.org/10.1016/j.biortech.2014.10.013

Song H, Liu G, Wu J (2016) Pyrolysis characteristics and kinetics of low rank coals by distributed activation energy model. Energy Convers Manag 126:1037-1046

Wang Y, Song Y, Zhi K, Li Y, Teng Y, He R, Liu Q (2017) Combustion kinetics of Chinese Shenhua raw coal and its pyrolysis carbocoal. J Energy Inst 90(4):624-633

Zhang D, Liu P, Lu X, Wang L, Pan T (2015) Upgrading of low rank coal by hydrothermal treatment: coal tar yield during pyrolysis. Fuel Process Technol 141:117-122. https://doi.org/10.1016/j. fuproc.2015.06.037 